\title{
PERMAINAN ULAR TANGGA BERBASIS CERITA RAKYAT ENDE-LIO UNTUK MENINGKATKAN KOSAKATA BAHASA INGGRIS
}

\author{
Yuliani Sepe Wangge ${ }^{1}$, Nining Sar'iyyah ${ }^{2}$ \\ yulianisw15@gmail.com ${ }^{1}$, sariyyah.nining@gmail.com² \\ PGSD, FKIP, Universitas Flores ${ }^{12}$
}

\begin{abstract}
Abstrak: Tujuan penlitian ini adalah untuk meningkatkan kosa kata bahasa Inggris pada mahasiswa PGSD Uniflor melalui permainan ular tangga berbasis cerita rakyat Ende Lio. Penelitian ini merupakan penelitian tindakan kelas yang melalui tahapan persiapan, tindakan, observasi dan refleksi. Setelah diterapkan permainan ular tangga berbasis cerita rakyat Ende-Lio dalam dua siklus, di temukan adanya peningkatan kosa kata bahasa Inggris pada mahasiswa PGSD Universitas Flores.
\end{abstract}

Kata kunci: permainan ular tangga, cerita rakyat ende-lio, kosakata bahasa Inggris

\section{SNAKE LADDER GAME BASED ON ENDE LIO'S FOLKLORE TO IMPROVE ENGLISH VOCABULARY}

\begin{abstract}
The purpose of this research is to improve English Vocabulary through Ende Lio folklore based snake ladder games. This research is a classroom action research through the stages of planning, action, observation and reflection. After applying the snake lader games based on folklore Ende Lio in two cycles, it was found that there was an increase in English vocabulary at PGSD students at Flores University.
\end{abstract}

Keywords: snake ladder game, ende lio's folklore, English vocabulary.

\section{PENDAHULUAN}

Bahasa Inggris lazimnya merupakan bahasa asing yang dapat menghubungkan seseorang dengan dunia luar. Hampir dalam segala aspek pergaulan, bahasa Inggris selalu dijumpai baik lisan maupun tulisan. Sebagai salah satu bahasa internasional, di Indonesia bahasa Inggris dimasukan ke dalam kurikulum baik pada tingkat dasar maupun perguruan tinggi. Bahkan di level perguruan tinggi bahasa asing ini menjadi mata kuliah wajib di setiap program studi. 
Yuliani, Nining, Permainan Ular Tangga Berbasis...

Ada tiga elemen dalam mempelajari bahasa Inggris yakni kosa kata atau vocabulary, pelafalan atau pronounciation, dan struktur bahasa atau grammar (Megawati, 2016). Kemampuan menguasai vocabulary merupakan landasan utama dalam mempelajari bahasa Inggris baik itu dalam proses membaca, menyimak, maupun berbicara. Tanpa penguasaan vocabulary yang banyak, seorang peserta didik tidak akan mampu berkomunikasi dengan baik.

Kesulitan menguasai vocabulary merupakan hal yang lumrah terjadi pada peserta didik yang mempelajari bahasa Inggris. Kenyataan ini juga sering terjadi pada level perguruan tinggi, seperti yang dialami mahasiswa PGSD Universitas Flores. Mahasiswa sulit memahami isi bacaan dalam bahasa Inggris karena rendahnya penguasaan vocabulary. Hal ini membuat proses perkuliahan cenderung pasif dan searah. Mengingat pentingnya penguasaan bahasa asing ini, maka perlu dilakukan terobosan dalam proses perkuliahan dengan tujuan meningkatkan vocabulary pada mahasiswa.

Banyak trik jitu yang dapat dilakukan instruktur untuk memperkaya vocabulary bahasa asing, salah satunya melalui metode permainan. Permainan merupakan teknik belajar yang efektif karena memiliki kelebihan menghibur dan memungkinkan adanya partisipasi aktif peserta didik (Sardiman dalam Yumarlin, 2013). Ular Tangga adalah jenis permainan klasik yang umumnya sangat familiar dengan siapa saja. Ular tangga merupakan salah satu bentuk permainan yang menggunakan papan sederhana, dadu dan bidak (Kusrini, 2012).

Selain familiar, Ular Tangga merupakan sebuah bentuk permainan yang fleksibel dan edukatif sehingga kerap dijadikan media pembelajaran di lembaga pendidikan. Salah satu bentuk modifikasi permainan ini adalah dengan mengkombinasikan cerita rakyat ke dalam tema permainan. Banyak cerita rakyat yang dapat disisipkan ke dalam permainan ular tangga. Salah satunya adalah cerita rakyat asli suku Ende-Lio, seperti ine pare, Asal Usul Danau Kelimutu, Ia Meja dan Wongge, serta Lawi Luja.

Permainan ular tangga berbasis cerita rakyat Ende-Lio dapat dijadikan salah satu alternative pembelajaran yang dapat meningkatkan vocabulary bahasa Inggris Hal ini telah dikaji secara ilmiah dalam penelitian Safitri (2016) pada siswa kelas IV sekolah dasar. Hasil penelitian menunjukkan adanya peningkatan nilai setelah diterapkan 
Yuliani, Nining, Permainan Ular Tangga Berbasis...

modifikasi permainan tersebut. Begitupun dalam dalam penelitian Suganda, Hidayat dan Widayastuti (2010) serta penelitian Pertiwi (2018) membuktikan permainan ular tangga dapat meningkatkan kosa kata bahasa Inggris pada siswa sekolah dasar. Merujuk pada hal tersebut, maka dapat diterapkan media belajar yang sama pada mahasiswa PGSD Universitas Flores sebagai upaya dalam meningkatkan kosa kata bahasa Inggris

\section{METODE}

Penelitian ini merupakan jenis penelitian tindakan kelas dimana peneliti berupaya untuk meningkatkan kosa kata bahasa Inggris pada subyek penelitian yakni mahasiswa PGSD Uniflor semester genap yang program mata kuliah bahasa Inggris. Prosedur penelitian dilakukan secara siklik melalui tahap perencanaan, tahap tindakan, tahap observasi dan tahap refleksi. Data diambil dengan teknik tes, dokumentasi dan catatan lapangan untuk merekam proses perkuliahan. Data-data tersebut dianalisis melalui tahapan reduksi data, penyajian data dan penarikan kesimpulan. Keberhasilan tindakan ditandai dengan adanya pencapaian ketuntasan perkuliahan minimal sebesar 90\% setelah diterapkan permainan ular tangga berbasis cerita rakyat Ende-Lio. Apabila telah mencapai target yang diinginkan, maka penelitian secara siklik dihentikan.

\section{HASIL}

Penelitian ini bertujuan untuk dapat meningkatkan penguasaan kosa kata bahasa Inggris dengan menerapkan media permainan ular tangga. Adapun hasil penelitian, dapat dilihat pada Tabel 1 .

\section{Tabel 1 Peningkatan Penguasaan Kosa Kata Bahasa Inggris Setelah Diterapkan Permainan Ular Tangga berbasis Cerita Rakyat Ende-Lio}

\begin{tabular}{|c|c|c|c|}
\hline \multirow{2}{*}{ No } & \multirow{2}{*}{$\begin{array}{c}\text { Indikator Penguasaan Kosa } \\
\text { Kata Bahasa Inggris }\end{array}$} & \multicolumn{2}{|c|}{ Persentase (\%) } \\
\cline { 3 - 4 } & Siklus I & Siklus II \\
\hline $\mathbf{1}$ & Menemukan arti kata & 69 & 95 \\
\hline $\mathbf{2}$ & Memilih kosa kata & 67 & 89 \\
\hline $\mathbf{3}$ & Menggunakan Kosa kata & 68 & 94 \\
\hline \multicolumn{2}{r}{ Rata-rata } & 68 & 93 \\
\hline
\end{tabular}

Berdasarkan data pada Tabel 1 menunjukkan persentase penguasaan kosa kata sebesar $68 \%$ pada siklus I. Pada siklus II terjadi peningkatan penguasaan kosa kata 
Yuliani, Nining, Permainan Ular Tangga Berbasis...

bahasa Inggris menjadi 93\%. Angka tersebut telah memenuhi target yang diinginkan yakni 90\%. Dengan demikian, penelitian dengan menerapkan permainan ular tangga berbasis cerita rakyat Ende-Lio telah berhasil meningkatkan penguasaan kosa kata Bahasa Inggris mahasiswa PGSD Uniflor pada siklus II.

\section{PEMBAHASAN}

Peningkatan persentase penguasaan kosa kata bahasa Inggris pada Tabel 1 tidak terlepas dari prosedur pelaksanaan penelitian yang menerapkan media permainan ular tangga berbasis cerita rakyat Ende-Lio. Langkah penerapan tersebut melalui tahap perencanaan, tahap tindakan, tahap observasi dan tahap refleksi selama dua siklus. Adapun tahap perencanaan dilakukan dengan mempersiapkan media permainan ular tangga berbasis cerita rakyat Ende-Lio yang meliputi papan permainan bergambar ular tangga yang desain gambarnya diunduh dari internet. Papan tersebut terdiri atas 100 kotak. Tiap baris pada papan berjumlah 10 kotak, begitupun pada kolom papan juga berjumlah 10 kotak. Setiap kotak berisikan perintah dan pertanyaan tentang kosa kata bahasa Inggris dalam tema cerita rakyat suku Ende-Lio. Selain papan, peneliti juga mempersiapkan kelengkapan lain seperti dadu, bidak, kartu pertanyaan dan 4 teks cerita rakyat Ende-Lio yaitu Ine Pare, Asal Usul Danau Kelimutu, Ia Meja dan Wongge serta Luwi Luja.

Setelah persiapan matang, dilakukanlah tahap tindakan yang menerapkan permainan ular tangga berbasis cerita rakyat Ende Lio. Proses perkuliahan diawali dengan memberikan arahan terlebih dahulu mengenai langkah pembelajaran dan peraturan permainan ular tangga. Selanjutnya mahasiswa dibagi ke dalam beberapa grup yang terdiri atas 4 anggota. Tiap grup diberikan teks cerita rakyat Ende-Lio, bidak, dadu, kartu pertanyaan dan papan permainan ular tangga. Kemudian mahasiswa ditugaskan untuk membaca seluruh teks tersebut sebelum menjalankan bidak lazimnya permainan ular tangga. Setiap anggota pun secara bergiliran melempar dadu dan menjalankan bidak sesuai jumlah mata dadu yang keluar. Pemain wajib menjawab pertanyaan ataupun melakukan perintah sesuai kartu pertanyaan di kotak perhentian bidak. Apabila menjawab dengan benar diberi skor sesuai bobot pertanyaan.. Setelah seluruh kelompok menyelesaikan permainannya, tiap mahasiswa kembali diberi tes untuk mengukur penguasaan kosa kata bahasa Inggris. 
Yuliani, Nining, Permainan Ular Tangga Berbasis...

Selama proses tindakan, tahapan observasi ikut dilaksanakan. Ada dua observer yang memantau tahap tindakan. Pada tahap tindakan siklus I ditemukan kelemahan yang menghambat kegiatan perkuliahan yakni mahasiswa tidak membawa kamus bahasa Inggris sehingga menyulitkan proses perkuliahan. Selain itu juga ditemukan adanya rasa kurang percaya diri pada mahasiswa saat salah mengeja beberapa kosa kata. Sedangkan hasil refleksi siklus I dan II dapat dilihat pada Tabel 2.

\section{Tabel 2 Hasil Refleksi Siklus I dan Siklus II}

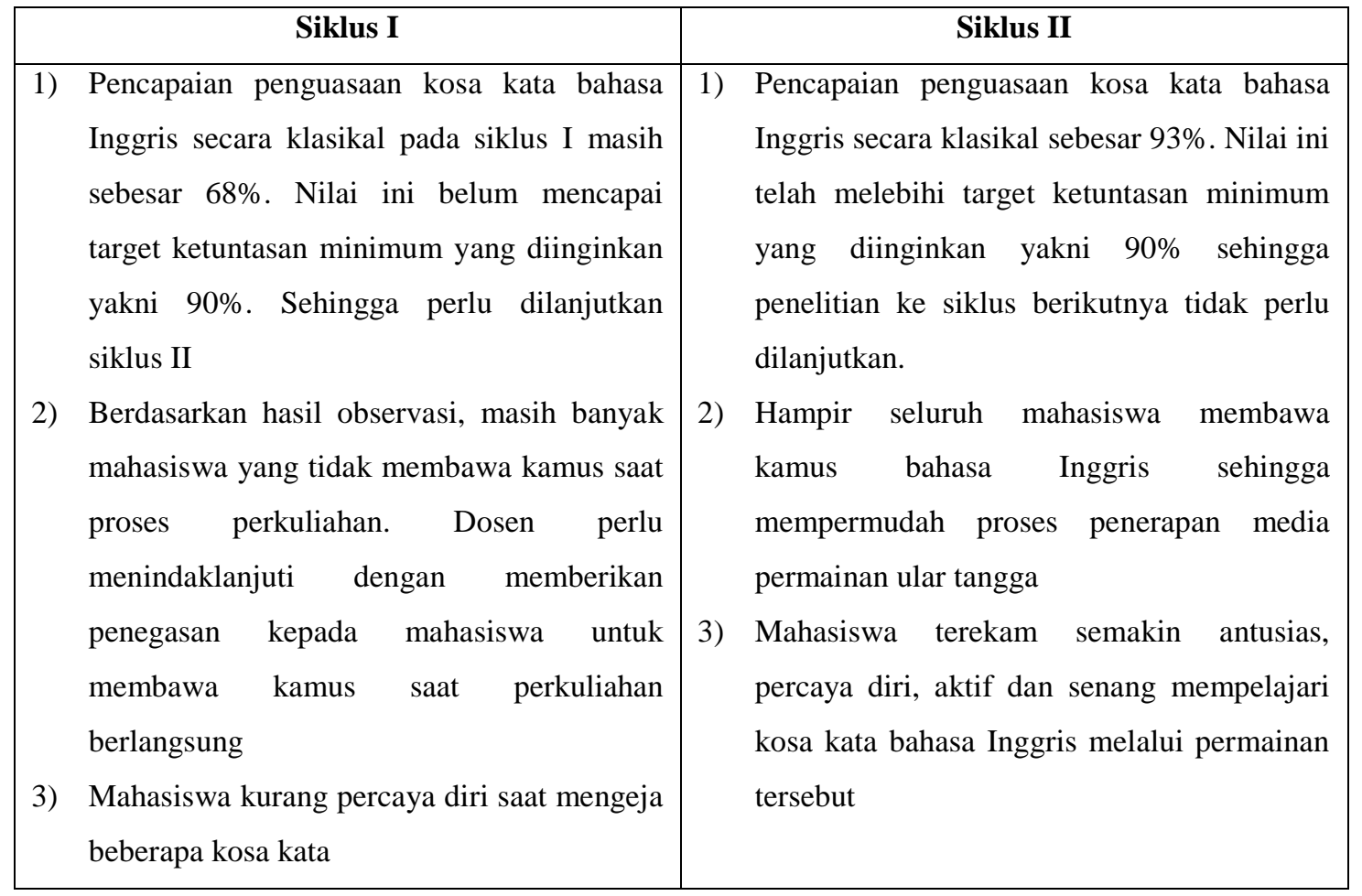

Berdasarkan kegiatan refleksi sesuai Tabel 2, dapat ditarik sebuah kesimpulan bahwa permainan ular tangga berbasis cerita rakyat Ende-Lio dapat meningkatkan penguasaan kosa kata bahasa Inggris pada mahasiswa PGSD Universitas Flores. Peningkatan tersebut tidak terlepas dari manfaat permainan itu sendiri yakni sebagai salah satu sarana untuk menghibur. Melalui fungsi tersebut, membantu mahasiswa menjadi lebih rileks secara emosional dalam mempelajari bahasa Inggris yang sebelumya dianggap sulit. Fakta ini sejalan dengan pandangan Freeman (dalam Munandar, 1995) bahwa bermain merupakan aktivitas yang membantu membantu anak mencapai perkembangan yang utuh, baik fisik, intelektual, sosial, moral dan emosioal. 
Yuliani, Nining, Permainan Ular Tangga Berbasis...

Penggunaan cerita rakyat Ende-Lio merupakan pengalaman baru bagi mahasiswa dalam mempelajari bahasa Inggris. Walaupun sedang mempelajari bahasa asing, mahasiswa tetap merasa tidak asing karena mempelajari konten yang familiar dengan budayanya sendiri. Hal ini memberikan kemudahan bagi mahasiswa untuk memahami isi teks bacaan yang dipelajari sehingga mampu meningkatkan penguasaan kosa kata bahasa Inggris

\section{SIMPULAN}

Berdasarkan hasil penelitian siklus I menunjukkan persentase rata-rata ketuntasan sebesar $68 \%$ pada siklus I dan $93 \%$ pada siklus II. Hasil ini menunjukkan telah terjadi peningkatan penguasaan kosa kata bahasa Inggris setelah diterapkan media permainan ular tangga berbasis cerita rakyat Ende-Lio.

\section{DAFTAR PUSTAKA}

Hapsari dan Suminar. 2011. Efektifitas Ludo Words Game (LWG) Terhadap Peningkatan Kosa Kata Bahasa Inggris Pada Anak (Studi Kasus pada Siswa kelas IV SD Muhammadiyah 4 Pucang. Artikel Penelitian. https://scholar.google.co.id

Kusrini, E. 2012. Teaching Vocabulary for Junior High School Students Using Snake and Ladder Game. Jurnal Aktif, Volume XIX Nomor 4. https://scholar.google.co.id

Megawati, F. 2016. Kesulitan Mahasiswa dalam Mencapai Pembelajaran Bahasa Inggris Secara Efektif. Jurnal Pedagogia, volume 5, no. 2. https://scholar.google.co.id Munandar, U.S.C. 1995. Bimbingan dan Koseling Anak Berbakat. Surabaya: Makalah dalam Kongres VIII dan Konvensi Nasional X IPBI.

Pertiwi, V. F. D. (2018). Perbedaan Penggunaan Metode Ceramah dan Metode Permainan Ular Tangga dalam Meningkatkan Hasil Belajar Kosakata Bahasa Inggris Siswa Sekolah Dasar (Doctoral dissertation, Unika Soegijapranata Semarang).

Safitri, A. H. (2016). Penggunaan Media Permainan Ular Tangga untuk Meningkatkan Keterampilan Menyimak Cerita Wayang Purwa Lakon Gathutkaca Lair. 
Yuliani, Nining, Permainan Ular Tangga Berbasis...

Suganda, A., Hidayat, A., \& Indri Widayastuti, E. R. (2010). Upaya meningkatkan kemampuan bicara siswa dalam bahasa inggris melalui permainan sanke and ladder di kelas VII A SMP negeri cimahi. Bandung: UPI.

Yumarlin. 2013. Pengembangan Permainan Ular Tangga Untuk Kuis Mata Pelajaran Sains Sekolah Dasar. Jurnal Teknik Volume 3 Nomor 1. https://scholar.google.co.id 